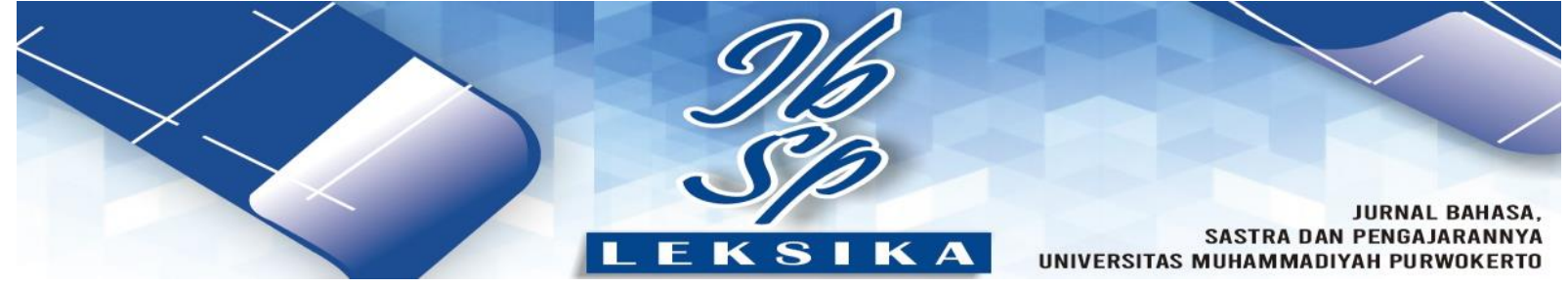

\title{
Translation of "and" by students of Mandarin Language Diploma : a translation evaluation
}

\author{
Henggar Prasetyowati*, Adilla Achmad Syahputri, Zuyinatul Isro, Chendy Arieshanty \\ Universitas Jenderal Soedirman
}

\begin{abstract}
This study examined the technique and quality of the translation of the conjunctions "and" done by students in socio-cultural subjects. The researchers conducted observations on the translation of students of the Universitas Jenderal Soedirman (Unsoed) Chinese Language Diploma Program (D3) who enrolled in the socio-cultural translation course. The results of their translation were then analyzed in the sense of their techniques used and the quality of their translation. Moreover, questionnaires were distributed to get suggestions for improvements to the teaching system, especially translation. The results showed that the error was dominated by the ambiguity of meaning caused by the incorrect choice of conjunctions, while the technique used was not entirely correct. This happens due to the lack of student competence, especially in mastering words and contexts of the conjunctions used.
\end{abstract}

Keywords: conjunctions, translation, Chinese language

Article History: Recieved 10 Jan 2022, Final revision 19 Feb 2022, Published 27 Feb 2022

\section{Introduction}

Translation is a process of trying to transfer the language from the source language (SL) into the target language (TL). Munday (2001) defined translation "as changing of original written texts in the original verbal language into written texts in a different verbal language". The high demand for human resources who master the Chinese language encourages the Diploma Program (D3) of Chinese Language at Universitas Jenderal Soedirman to produce graduates with those criteria. This makes the D3 Chinese Language a three-diploma level study program with final majors in tourism and Mandarin translation. The main competencies in learning language are speaking, reading, listening, and writing skills. Besides the four main competencies, students also deepen their translation skills, both spoken and written, in various fields including tourism. To achieve these major skills and translating skills, the D3 Chinese Language of Unsoed provides materials according to the level for basic Mandarin competencies such as Chuji Shuxie, namely a Chinese language writing proficiency course for elementary level students and Zhongji Shuxie for third and fourth-semester students. Supporting basic specialization (translation and tourism) courses such as translation theory and tourism basics were offered from the first semester supplemented with the translation package course in the fifth semester.

Nida and Taber (1982) define translation as "reproducing in the receptor language the closest natural equivalent of the source language message, first in terms of meaning and secondly in terms of style". Producing a good translation means not only translating one language into another but also having to consider the meaning of the sentence. A conjunction is one of the important instruments in the text that function to connect events, qualities, or ideas between a clause and a group of clauses. The importance of understanding the position of conjunctions affects the translator's understanding of the text to be translated and the quality of the translation. The number of things that are required to be mastered in order to produce a good quality translation is certainly not an easy thing that can be mastered by diploma program graduates, and this is what encouraged the researchers to improve the understanding of conjunctions contained in a text, which might

*Corresponding authors: J1. DR. Soeparno No.60, Karangwangkal, Kec. Purwokerto Utara, Kabupaten Banyumas, Jawa Tengah 53122. Email: henggarpr@unsoed.ac.id DOI: 10.30595/lks.v\%vi\%i.12761, @2022 Leksika. All rights reserved. 
help students to produce a quality translated text.

Semantics is a linguistic sub-domain that examines meaning in language (Tarjana, 2013). It is further said that meaning is a multifaceted phenomenon; indicating that people can see meaning from various perspectives, from the many branches of linguistics that exist. In this study, the researchers limited the study only to the semantic level. This study was conducted by using error analysis with the following procedures: 1) collecting error samples, 2)

\section{Method}

This study employed qualitative research where the data were collected using observation on 44 student translations with 4 "and" words in 3 sentences. In this study, researchers used the modified data analysis technique that the experts revealed in Tarigan

\section{Findings and Discussion}

Based on the analysis conducted on students' translated discourse, the results focused on discussing the use of conjunction "and" that are very closely related to the context of the discourse.

SL: Mulai dari kondisi emosi yang masih labil, semangat berkarya yang sangat tinggi serta keinginan untuk bisa tampil eksis dan ${ }^{1}$ ingin diakui oleh lingkungannya. (Starting from the emotional state that is still unstable, the enthusiasm for work is very highly and the desire to be able to appear and want to be recognized by the environment.)

SL: Ketika aktivitas yang mereka bangun itu adalah aktivitas kreatifyang baik dan ${ }^{2}$ dapat menghasilkan banyak karya tentu para remaja di dalamnya akan sangat terbantu menyalurkan semangat dan ${ }^{3}$ ide kreatif mereka dan memperoleh sebuah eksistensi diri yang positif terhadap lingkungan sosialnya. (When the activity they build is a good creative activity and can produce a lot of work, of course the teenagers in it will be very helpful in channeling their identifying errors, 3) explaining errors, 4) classifying errors, and 5) evaluating errors.

The issues to be studied related to the ability to translate Indonesian into the Mandarin were as follows: 1) The accuracy of the selection of techniques and the equivalent meaning of the conjunction "and" 2) Knowing the factors that affect the translation error of the conjunction "and" 3) finding the most appropriate way to produce an accurate translation, especially in the use of the conjunction "and".

(1998:62). The followings are the modified data analysis technique used in this study: 1) classifying data, 2) classifying errors, 3) describing errors, 4) correcting errors, 5) finding the cause of errors and FGD. Focus Group Discussions were conducted to determine techniques and find reasons for translation errors.

passion and creative ideas and obtaining a positive self-existence in their social environment.)

SL: Sementara itu dalam ruang lingkup media sosial mendapat perhatian dan ${ }^{4}$ menumbuhkan citra dapat dikategorkan dengan ke-eksistensian diri. (Meanwhile, within the scope of social media getting attention and growing an image can be categorized as self-existence.)

Conjunction "and" in Tata Bahasa Baku Bahasa Indonesia (2017:513) is included in the category of additional forms with additive meaning. This kind of conjunction functions to add events or descriptions of qualities that are parallel to the previous clause. The main feature of the semantic clause connected by the conjunction "and" does not express the difference in message level. (Tata Bahasa Baku Bahasa Indonesia: 2017: 517)

The results from Focus Group Discussions focused on discussing of the analysis of the translation of conjunction "and" techniques are as follows:

Table 1. Translation results of the conjunction "and"1

\begin{tabular}{lll}
\hline \multicolumn{1}{c}{ Translation } & \multicolumn{1}{c}{ Technique } & \multicolumn{1}{c}{ Total } \\
\hline 并 & Literal & 10 \\
也 & Discursive Creation & 6
\end{tabular}




\begin{tabular}{lll} 
和 & Established Equivalence & 9 \\
还有 & Discursive Creation & 3 \\
removed & Deletion & 16 \\
\hline
\end{tabular}

The table above presents that the majority of students, 16 of them, chose to remove the conjunction "and" contained in this "Mulai dari kondisi emosi yang masih labil, semangat berkarya yang sangat tinggi serta keinginan untuk bisa tampil eksis dan ${ }^{1}$ ingin diakui oleh lingkungannya" sentence using the deletion technique. Meanwhile, the use of the word 并 [bìng] in translating this conjunction indicates that there is a lack of understanding of the meaning of 并 [bìng]. 并 [bìng] indeed means and, but 并 [bìng] is and which means one level more than the previous clause, while in the SL sentence connects two parallel clauses. The same thing happens with the use of conjunction 也[yě]. Although the conjunction 也[yě] has a similar form and meaning as the conjunction "and", it has a different function. The word 也[yě] which means also is not appropriate for translating the word and in the SL. The most appropriate way to translate the conjunction "and" in this sentence is the conjunction 和 [hé] used to refer to the parallels of things connected in the sentence. The use of inappropriate conjunctions causes the quality of the translation to decrease, both in terms of accuracy, acceptability, and readability.

Table 2. Translation results of the conjunction "and"2

\begin{tabular}{lll}
\hline \multicolumn{1}{c}{ Translation } & \multicolumn{1}{c}{ Technique } & \multicolumn{1}{c}{ Total } \\
\hline 并且 & Established Equivalence & 7 \\
并 & Literal & 29 \\
和 & Literal & 2 \\
removed & Deletion & 6 \\
\hline
\end{tabular}

The table 2 above presents that the majority of students, 29 of them, choose to translate the conjunction "and" 2 contained in this "Ketika aktivitas yang mereka bangun itu adalah aktivitas kreatif yang baik dan ${ }^{2}$ dapat menghasilkan banyak karya tentu para remaja di dalamnya akan sangat terbantu menyalurkan semangat dan ${ }^{3}$ ide kreatif mereka dan memperoleh sebuah eksistensi diri yang positif terhadap lingkungan sosialnya." sentence using the literal technique. Meanwhile, the use of the word 并 [bìng] in translating this conjunction indicates that there is a lack of understanding of the meaning of 并 [bìng]. 并 [bìng] indeed means and, but 并 [bìng] is and which means one level more than the previous clause, while in the SL sentence connects two parallel clauses. The same thing happens with the use of conjunction 和 [hé]. conjunction 和 [hé] used to refer to the parallels of things connected in the sentence. According to the

Table 3. Translation results of the conjunction "and"3

\begin{tabular}{lll}
\hline \multicolumn{1}{c}{ Translation } & \multicolumn{1}{c}{ Technique } & \multicolumn{1}{c}{ Total } \\
\hline 并 & Established Equivalence & 16 \\
以及 & Literal & 25 \\
removed & Deletion & 3 \\
\hline
\end{tabular}

The table 3 above presents that the majority of students, 25 of them, choose to translate the results of the FGD, there is a meaning of "then" in the conjunction "and" in clause "ketika aktivitas yang mereka bangun itu adalah aktivitas kreatif yang baik dan ${ }^{2}$ dapat menghasilkan banyak karya". This is in accordance with the example below "SL : "aku bersepeda dan memanggil dia"

$T T$ : 我骑自行车并且喊他。( Yu, Zhang Qiong,1993:257)

In the example sentence above, it shows "并 且." (and) as a connector between two clauses that are not fully equivalent, in the middle of the sentence there should be no other insertions or commas. (Yu, Zhang Qiong, 1993:257). Based on this explanation the most appropriate way to translate the conjunction "and"2 in this sentence is the conjunction “并且"[bìngqiě]. The use of inappropriate conjunctions causes the quality of the translation to decrease, both in terms of accuracy, acceptability, and readability. conjunction "and"3 contained in this "Ketika aktivitas yang mereka bangun itu adalah aktivitas 
kreatif yang baik dan ${ }^{2}$ dapat menghasilkan banyak karya tentu para remaja di dalamnya akan sangat terbantu menyalurkan semangat dan ${ }^{3}$ ide kreatif mereka dan memperoleh sebuah eksistensi diri yang positif terhadap lingkungan sosialnya." sentence using the literal technique. Meanwhile, the use of the word 以及 [yǐí] in translating this conjunction indicates that there is a lack of understanding of the meaning of 以及 [y̌iji]. 以 及 [y̌iji] indeed means and, 以及 [y̌jí] is and which used to connect two clauses in the main sentence which is generally still followed by a subordinate clause, sometimes it can mean "and also". (Chuan, Peng Xiao, $2016: 260$ )

According to the results of the FGD, there is a meaning of "for" in the conjunction "and" in clause "tentu para remaja di dalamnya akan sangat terbantu menyalurkan semangat dan ${ }^{3}$ ide kreatif mereka dan memperoleh sebuah eksistensi diri yang positif terhadap lingkungan sosialnya". This is in accordance with the example below

"SL: "aku duduk dan mendengarkan radio"

TT：我坐着并听收音机。( $\mathrm{Yu}$, Zhang Qiong,1993:257)

In the example sentence above, it shows "并 "[bìng] (and) as a connector between two clauses that are not fully equivalent, in the middle of the sentence there should be no other insertions. (Yu, Zhang Qiong, 1993:257). Based on this explanation, the most appropriate way to translate the conjunction "and" 3 in this sentence is the conjunction "并 "[bìng]. The use of inappropriate conjunctions causes the quality of the translation to decrease, both in terms of accuracy, acceptability, and readability.

Table 4. Translation results of the conjunction "and" 4

\begin{tabular}{lll}
\hline \multicolumn{1}{c}{ Translation } & \multicolumn{1}{c}{ Technique } & \multicolumn{1}{c}{ Total } \\
\hline 和 & Established Equivalence & 34 \\
并 & Literal & 3 \\
removed & Deletion & 7 \\
\hline
\end{tabular}

The table 4 above presents that the majority of students, 34 of them, choose to translate the conjunction "and" 3 contained in this "Sementara itu dalam ruang lingkup media sosial mendapat perhatian dan menumbuhkan citra dapat dikategorkan dengan ke-eksistensian diri." sentence using the Established Equivalence technique. According to the results of the FGD, the meaning of "and" in sentence "Sementara itu dalam ruang lingkup media sosial mendapat perhatian dan ${ }^{4}$ menumbuhkan citra dapat dikategorkan dengan ke-eksistensian diri."

Based on this explanation, the most appropriate way to translate the conjunction "and" in this sentence is the conjunction 和 [hé] used to refer to the parallels of things connected in the sentence. The use of inappropriate conjunctions has made the translation quality to decrease, in terms of accuracy, acceptability, and readability.

Students' understanding of the existence of conjunctions in sentences, both in Indonesian and in Mandarin, can be seen from the research findings and FGD discussions that have been described above. Especially the focus in this research is the use of the conjunction "and" which has a function meaning as a link between clauses and adding incident information. In contrast to Indonesian, in Mandarin, clauses can be linked without the word "and" explicitly appearing.

Wang (2016) compared the use of conjunctions in learning mathematics, which was used by teachers and students during learning. In addition to dividing the subject into two, namely the use of conjunctions by teachers and students to see whether the use of conjunctions is internal or external, Wang also compares it with two languages. That is a mathematics learning in the U.S. which uses English and in China which uses Mandarin. The research conducted by Wang did not look at the translation results between the two languages but compared whether language differences would affect the differences in the use of conjunctions used by teachers and students during learning. The results of the research will then be calculated statistically.

The authors have not found any research that focuses on the translation of conjunctions from Indonesian into Mandarin or vice versa. Several studies were found that discussed research on the translation of conjunctions, such as research conducted by Lestari where she saw the shift that occurred in Barack Obama's speech from English into Indonesian. The 
results of his research show that there is a translation shift in translating conjunction relationships. Where the shift can be seen from the changing logical meaning in SL which is different from the logical meaning in TL. For example, the phrase "and later" which has a sequential logical meaning is translated into "and" which has an additive-additive logical meaning. The same thing was also found in research conducted by Ulfa who researched conjunction relationships in the novel The Vampire Diaries. Where it was found that there was a shift in the conjunction relationship from the word "and" which was included in the

\section{Conclusion}

Based on the study that has been conducted through data collection and FGD, the results indicate that the technique that most often appears is the literal technique by translating without considering the meaning in the context of using the conjunction. In other words, the average student had not been able to accurately translate conjunctions from Indonesian into Mandarin, especially the conjunctions "and." Meanwhile, the use of the deletion technique followed by the creation of discourse was caused by a lack of understanding of the function and position of the conjunction itself in the sentence, causing the majority of inaccuracies in the choice of words that were not commensurate. Students

\section{References}

Jianqin, W. (2012). 第二语言习得研究. Beijing: 商务印书馆出版社.

Lestari, U.D., Nababan., M.R., Santosa, R. (2013). Analisis Terjemahan Hubungan Konjungtif (HK): Bentuk Pergeseran, Gaya Bahasa, dan Kualitas Terjemahan pada TeksTeks Pidato Resmi Presiden ad "Barack Obama". Tesis. Universitas Sebelas Maret

Molina, L., Albir, A. H. (2002). Translation techniques revisited: A dynamic and functionalist approach. Meta: Translator's Journal, 47(4), 498-512. https://doi.org/10.7202/008033ar

Nababan, M.R. (2003). Teori menerjemahkan bahasa Inggris. Yogyakarta: Pustaka Pelajar category of additive logical meaning to "medium" which was included in the comparative - opposite logical meaning.

The research findings are in line with the findings found by the researcher. Furthermore, the researchers used the results of student translations as objects of research which the student was in the process of learning both in terms of language and translation. The selection of the inappropriate conjunction of the conjunction and the omission of the meaning of the inappropriate conjunction shows the level of student ability that is lacking in terms of these two aspects.

also tended to delete these conjunctions by using a deletion technique to remove the conjunctive link between one event and another, thus affecting the quality of translation and the logic of the discourse as a whole.

Based on the description above, the role of the teacher or lecturer in translation and grammar courses is required to improve students' understanding of the proper function of conjunctions and translations in Indonesian. The researchers assume that it is necessary to develop a dictionary of conjunctions and even other groups of words from the IndonesianMandarin in order to help increase understanding and knowledge to properly translate conjunctions.

Nida, E.A., \& Taber, C.R. (1982). The theory and practice of translation. Leiden:E. J. Brill. https:doi.org/10/1017/S0009840X00016878

Pengxiao, C. (2016). 对外汉语教学语法 201 例.Beijing: 商务印书馆出版

Santosa, R. (2005). Logika Wacana : Hubungan Konjungtif dengan pendekatan Linguistik Sistemik Fungsional. Surakarta: UNS Press

Sukardi. (2003). Metodologi Penelitian Pendidikan. Jakarta: Bumi Aksara

Tarigan, H.G. (1988). Pengajaran Analisis Kesalahan Berbahasa. Bandung:

Tarjan, S.S. (2013). Semantik. UNS Press. Surakarta

Ulfa, Y.F., Nababan, M.R., Santosa, R. (2013). Pergeseran Hubungan Konjungtif dan 
Dampaknya Terhadap Kualitas Terjemahan dalam Novel Bergenre Naratif "The Vampire Diaries: The Awakening" (Sebuah Kajian terjemahan dengan Pendekatan Linguistik Sistemik Fungsional). Tesis. Universitas Sebelas Maret

Wang, S., Perry, C., Gonzales, G., Anderson, C., Huahua, C. (2016). Conjunction is more than just a grammatical resource: a comparative study of conjuction in US and Chinese mathematics lesson. Dissertation. University of Illinois at Urbana-Champaign. 2016

Windia, W dkk. (2009). Pemikiran Kritis Guru Besar Universitas Udayana : Peran Semantik dalam Penerjemahan. Denpasar: Udayana University Press

Zhangqiong, Y. (1993). 现代印尼语语法. Beijing: 外语教学与研究出版社 